\title{
Understanding Padangsidimpun City Community in Recognizing and Understanding Sharia Banking Products
}

\author{
Abdul Nasser Hasibuan ${ }^{1}$, Nofinawati ${ }^{2}$ \\ E-mail : hasibuanabdulnasser@iain-padangsidimpuan.ac.id \\ nofinawati@iain-padangsidimpuan.ac.id \\ 1,2Institut Agama Islam Negeri Padanngsidimpuan \\ 1,2Jl. H.T. Rizal Nurdin Km. 4,5 Sihitang, Padangsidimpuan, Sumatera Utara
}

\begin{abstract}
Abstrak
Penduduk kota Padangsidimpuan adalah 89\% Muslim yang tidak memahami perbankan syariah, dan menganggap perbankan syariah sama dengan bank konvensional. Tujuan dari penulisan ini adalah untuk mengetahui pemahaman masyarakat kota Padangsidimpun tentang produk perbankan syariah. Teori yang digunakan adalah pemahaman umum, pemahaman khusus, produk tentang perbankan syariah. Metode yang digunakan adalah PAR dimana strategi yang digunakan adalah proses pendekatan, penelitian, pembelajaran dan solusi teknis terhadap permasalahan sosial yang dapat direncanakan dan dilaksanakan bersama masyarakat. Hasil Pemahaman masyarakat tentang perbankan syariah hanya sebatas $84 \%$. Sedangkan hasil pemahaman khusus masyarakat kota Padangsdimpuan yaitu penjabaran produk syariah dan perbankan yaitu $12 \%$, sedangkan untuk tingkat kedua adalah pemahaman tafsir sebesar 73\%, dan untuk tingkat ketiga merupakan tingkat tertinggi. , yaitu pemahaman ekstrapolasi masyarakat kota Padangsidimpuan sebesar 63\%.
\end{abstract}

Kata Kunci: Pemahaman, Perbankan Syariah, Produk

\begin{abstract}
The population of Padangsidimpuan city is $89 \%$ Muslim who does not understand Islamic banking, and considers Islamic banking to be the same as conventional banks. The purpose of this paper is to determine the understanding of the people of Padangsidimpun city about Islamic banking products. The theory used is a general understanding, specific understanding, products about Islamic banking. The method used is PAR where the strategy used is a process of approach, research, learning and technical solutions to social problems that can be planned and implemented with the community. Results Public understanding of Islamic banking is only limited to $84 \%$. While the results of the specific understanding of the people of Padangsdimpuan city, namely the translation of Islamic products and banking, which is $12 \%$, while the second level is an understanding of interpretation of $73 \%$, and for the third level is the highest level, namely the understanding of extrapolation of the people of Padangsidimpuan city of $63 \%$.
\end{abstract}

Keywords: Understanding, Islamic Banking, Products

\section{Introduction}

Islamic Bank is a financial institution that has an intermediary function from two parties with excess and shortage of funds, which has the main task of collecting 


\section{Understanding Padangsidimpun City Community in Recognizing and Understanding Sharia Banking Products Abdul Nasser Hasibuan dan Nofinawati}

and distributing funds. Islamic banks raise funds with savings products, demand deposits and time deposits while Islamic banks distribute funds with financing products. According to Edy Wibowo, et al, (2005), Islamic banks in Indonesia operate according to sharia principles based on the provisions of the Qur'an and alHadith. Because in the Qur'an and al-Hadith it is regulated how to muamalah in Islam which in essence always always stays away from elements that contain usury, for collection and distribution activities are carried out on the basis of predetermined profit sharing.

Padangsidimpuan City with a population of 228,429 people, with an area of 146.87 Km2 has 6 sub-districts with 37 villages and 42 villages. In the city of Padangsidimpuan, there are 3 Islamic banking institutions operating. Where $89 \%$ of the people of Padangsidimpuan city, the majority of whom are Muslims, prefer banks with conventional principles to banks with sharia principles. The results of the initial survey on the community 6 in the district of Padangsidimpuan city, the cause of this is that there are still many people who have the same perception and knowledge about Islamic banks and conventional banks in their operational activities.

Based on a survey conducted from June 1 to June 22 2019, there were 10 respondents out of 50 respondents who had made transactions at Islamic banks, whether it was saving, financing or utilizing the services of Islamic banks. Those who use Islamic banks are just joining in, either following the advice of friends or family, or because the company they work for transfers their salaries through Islamic banks.

Then the results of the survey on August 1, 2019 people also still think that the management of operational activities of Islamic banks and conventional banks is the same, only my name is different if conventional banks use the interest system while Islamic banks use a profit sharing system or add sharia words. Those who have not used Islamic banks said they are not interested in using Islamic banks, there are also those who are reluctant to use Islamic banks because of complicated procedures. The thing that causes the ignorance of Islamic banks is that people say they have never received and participated in an education or socialization and Islamic financial assistance.

Mentoring is a job carried out by a facilitator, where mentoring recognizes and understands an activity or program. Meanwhile, the facilitator has the task only as a driver and motivator, while the actors and managers are the community itself. In 
connection with these mentoring activities, assistance from outside parties is needed, both individually and in groups. Where the task of this assistant is responsible for increasing awareness, in the context of meeting needs and solving problems that exist in the community.

Based on the background of the problem, it is necessary to provide community assistance as an effort to develop knowledge and understanding of the community in understanding and recognizing Islamic banking products. In this mentoring activity, the public will understand and know more about Islamic banking products and can distinguish conventional banks from Islamic banks in their operational activities.

\section{Literature Review}

Banking is a financial institution which in essence will increase economic growth, because the role of this institution will facilitate the process of a country's economic system. According to undiani (2009), there are six pillars in the Indonesian Banking Architecture (API) to realize a healthy, strong and efficient banking policy direction, namely:

1. A sound banking structure,

2. Effective regulatory system,

3. An independent and effective monitoring system,

4. Strong banking industry,

5. Sufficient supporting infrastructure,

6. Consumer protection.

The difference between Islamic banks and conventional banks is in the operational basis used, where conventional banks operate on an interest system, while Islamic banks operate on a profit-sharing, buying and selling system, and renting. This is based on the belief that bank interest contains elements of usury which is prohibited by Islam. In the Islamic view, the use of operations with an interest system contains an element of injustice caused by additional fees charged by the bank as an intermediary to those who have excess funds and those who lack funds (customers) or borrowers. Meanwhile, Islamic banks use a profit-sharing system while this system is the opposite of the interest system in conventional banking. Ascarya (2006) said that in this profit-sharing system, the excess funds 


\section{Understanding Padangsidimpun City Community in Recognizing and Understanding Sharia Banking Products \\ Abdul Nasser Hasibuan dan Nofinawati}

through intermediaries, namely Islamic banking and the lack of funds (borrowers) share risks and profits according to the agreement made at the beginning so that it does not only benefit one party.

According to Rianto Al-Arif, M.Nur (2012), Islamic banks offer a variety of products which are divided into three major parts, namely fund-raising products, financing products, and service products.

1) Funding Products, which consist of Savings, Time Deposits and Current Accounts. This product is regulated in the sharia banking law number 21 of 2008. This product of public fund collection is carried out with the wadi'ah principle and the mudharabah principle.

2) Product Distribution of Funds (financing), this product is given by one party to another party to support investments that have been planned by individuals or groups (institutions). In Islamic banking, financing products are run based on: a). The principle of buying and selling. Such as bai' murabahah, bai' as salam and bai' al istishna. b). Lease principle. Includes ijarah and ijarah muntahiya bit tamlik. c). Profit sharing principle. Includes musharaka, mudharabah, muzara'ah, and musaqah.

3) Service Products, these banking service products are aimed at customers, where the banking party gets a reward in the form of rent or profits that are charged to the customer. The banking service products include the following:

a. Sharf (foreign exchange trading)

b. Wadi'ah (deposit).

\section{Methods}

To conduct mentoring research, the researcher uses the PAR method where the strategy used is an approach process so that the research, learning and technical solutions of social problems can be carried out in a planned and carried out with the community.

PAR has three words that are always related to each other, namely participation, research and action, therefore for PAR researchers it is easier to do the work as follows: 1). Knowing the condition of the community (To Know), 2). Understanding society (to Understand), 3). Planning with the community (To Plann), 4). Take action, 5). Reflection/evaluation (To Reflection). Techniques for 
collecting and organizing data are interviews and mapping, with data analysis techniques, namely Venn diagrams, flow charts and problem tree analysis and expectations.

\section{Discussion}

\section{Community Service Results}

In the community service program activities that have been carried out, it is known that the participants enthusiastically participated in the socialization activities from the beginning to the end of the event, especially during the discussion session. The discussion was interesting because there was a lot of interaction between the presenters and participants about sharing experiences, problems and asking questions to deepen the material. Before and after the socialization of participants, freetest and posttest were conducted to measure the level of participants' understanding of Islamic banking.

Based on the test results that were distributed after the socialization was carried out in two sub-districts in the city of Padangsidimpuan which consisted of three questions, namely 1). Sharia Banking 2) Sharia Banking Products 3). The advantages of Islamic Banking are as follows:

The results of the public introduction test about Islamic banking can be seen in the following picture:

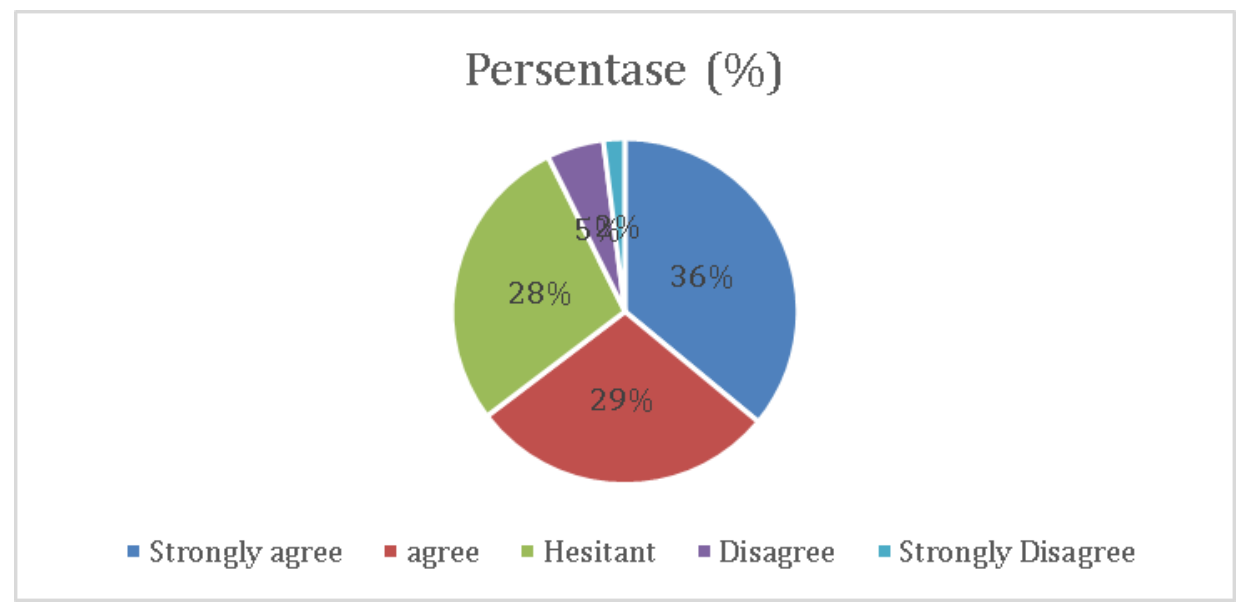

Figure 1

Result of Post test of Islamic Banking Socialization 


\section{Understanding Padangsidimpun City Community in Recognizing and Understanding Sharia Banking Products \\ Abdul Nasser Hasibuan dan Nofinawati}

Based on Figure 1 above, it can be seen that those who have the percentage value of participants after conducting socialization about Islamic banking who answered strongly agree as much as $36 \%$, agree as much as $29 \%$, doubt as much as $28 \%$, disagree $5 \%$ while those who answer strongly disagree as much as $2 \%$. Meanwhile, the results of the public introduction test about Islamic banking products can be seen in the following figure:

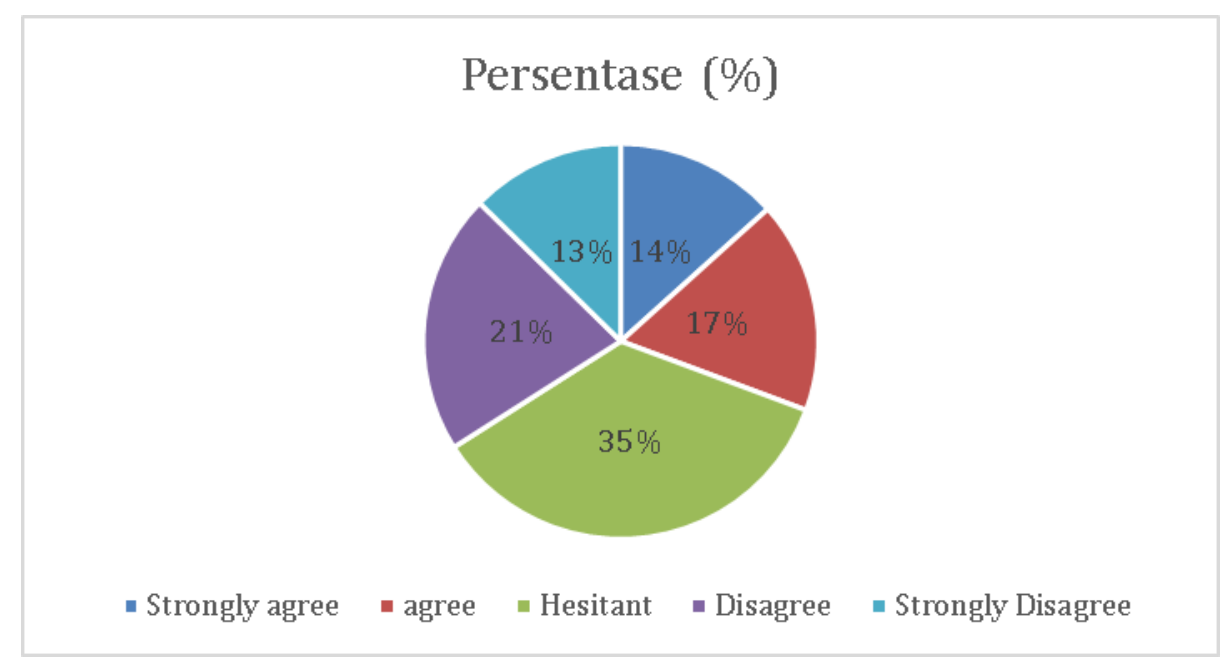

Figure 2

Post test results of Islamic Banking Excellence

Based on Figure 3 above, it can be seen that those who have the percentage value of the participants after conducting socialization about the advantages of Islamic banking who answered strongly agree as much as $34 \%$, agree as much as $32 \%$, hesitate as much as $29 \%$, disagree $5 \%$ while those who answer strongly disagree. agree as much as $0 \%$. The results of the free test and post-test scores are very significant in addition, it can be concluded that the socialization carried out was very successful in understanding Islamic banking.

From the results of the answers from the participants of the socialization, it can be concluded that the level of understanding of Islamic banking is shown as follows:

a. General Understanding of Islamic Banking

The results of this socialization also divide understanding into two, namely understanding (instructional understanding) which is an understanding only 
limited to knowing, and relational understanding (relational understanding) which is the understanding of having done what they know.

\section{Table 1}

\section{Understanding of Islamic Bank Respondents in General Before Socialization}

\begin{tabular}{|c|c|c|}
\hline No & Understanding Type & Amount \\
\hline 1. & Instructional understanding & 129 \\
\hline 2. & Relation understanding & 21 \\
\hline
\end{tabular}

\section{Response Level of Understanding of Islamic \\ Banks Before Socialization}

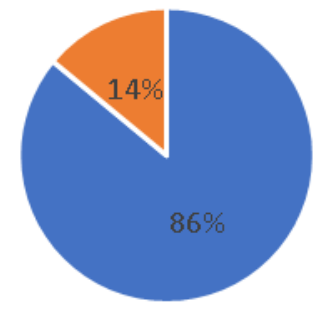

- instructional understanding - relation understanding

\section{Figure 3 \\ Understanding of Islamic Bank Respondents in General before Socialization}

The results of the socialization can be seen that the understanding of the people of Padangsidimpuan city about Islamic banks is still very low. Limited knowledge and the absence of promotion and socialization carried out by Islamic banks have caused some people not to know what Islamic banks are and what products are available in Islamic banks. This can be seen in Figure 4.15 where the people of Padangsidimpuan city only know about Islamic banks in general, such as the results of a questionnaire to respondents before socialization as much as $86 \%$, this community knowledge assumes that basically Islamic banks and conventional banks are different in terms of their operations and the products offered. Islamic banks are financial institutions whose main business is providing credit and services in payment traffic and 
circulation whose operations are adjusted to the principles of Islamic sharia. The difference between Islamic banks and conventional banks lies in the type of profit that banks take from the transactions they carry out. If conventional banks base profits from taking interest, then in Islamic banks there is no interest but is referred to as a reward, both in the form of services and profit sharing.

These results are very different after direct socialization to the community will be inversely proportional, this can be seen in the following table and figure:

Table 2

Understanding of Islamic Bank Respondents in General after Socialization

\begin{tabular}{|c|c|c|}
\hline No & Understanding Type & Amount \\
\hline 1. & Instructional understanding & 17 \\
\hline 2. & Relation understanding & 133 \\
\hline
\end{tabular}

Response Level of Understanding of Islamic Banks After Socialization

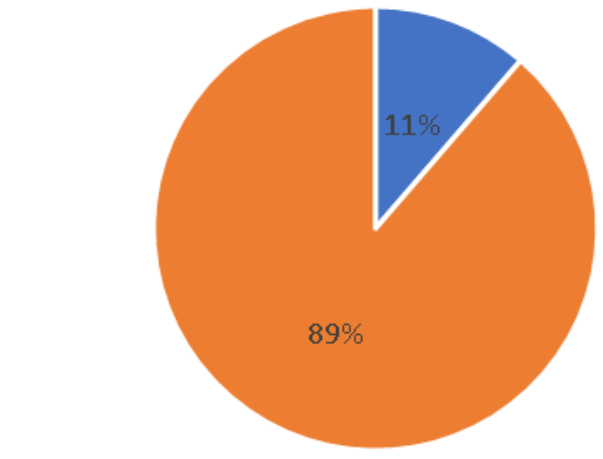

- instructional understanding = relation understanding

Figure 4.

Understanding of Islamic Bank Respondents in General after Socialization

In Figure 4. it can be seen that the understanding of Islamic bank respondents in general after socialization was $89 \%$, this result was inversely proportional to before the socialization was carried out, it was not in accordance with the actual reality of the community already knowing that 
Islamic banks are banks that adopt Islamic Sharia values which forbid usury. Based on information from all respondents who at the time of socialization, all of them answered that they did not know the products and services available in Islamic banks. Some people are already aware of the existence of Islamic banks, but they do not know the products offered by Islamic banks so that people who do not know the products of Islamic banks will certainly not be interested in using the services of Islamic banks because they consider that the supporting facilities provided are still inferior to those of Islamic banks. the facilities offered by conventional banks, but after socialization the community already understands the difference between Islamic banks and conventional banks and immediately has an account with a Sharia bank.

b. Specific Understanding of Islamic Banking

The results of this socialization also examine the level of understanding specifically by adopting the opinion of Nana Sudjana (1992) where understanding can be divided into three categories, namely:

1) The lowest level is the understanding of translation, starting from translating in the real sense, interpreting the principles of Islamic banking,

2) The second level is interpretive understanding, which is connecting the lowest parts with what is known next, or connecting with events, distinguishing the main from the non-essential,

3) The third level is the highest level, namely extrapolation understanding, understanding that can distinguish something, so that it can explain it and have applied it.

The findings of this study can be described as follows:

1. Public Understanding of Islamic Banking before Socialization

The following table and pictures of Islamic Bank Respondents' Understanding Specifically before the socialization, are as follows:

Table 3.

Understanding of Islamic Bank Respondents Specifically before Socialization

\begin{tabular}{|c|c|c|}
\hline No & Understanding Type & Amount \\
\hline $\mathbf{1 .}$ & Translation understanding & 76 \\
\hline
\end{tabular}


Understanding Padangsidimpun City Community in Recognizing and Understanding Sharia Banking Products

Abdul Nasser Hasibuan dan Nofinawati

\begin{tabular}{|c|c|c|}
\hline 2. & Interpretive understanding & 56 \\
\hline $3 \cdot$ & Extrapolation understanding & 18 \\
\hline
\end{tabular}

Respondents' Understanding of Islamic Banks

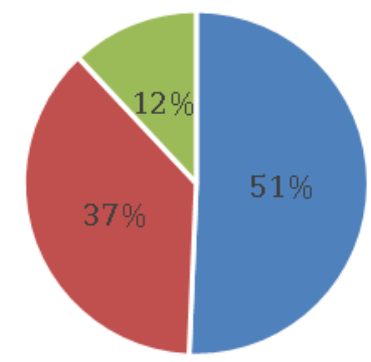

- translation understanding $\quad$ interpretation understanding

- extrapolation understanding

Figure 5 .

Understanding of Specific Respondents before Socialization is carried out

Based on Figure 5 the understanding of specific respondents before the socialization was carried out, it can be seen that the understanding of the translation was $51 \%$, this means that knowledge can be obtained through selfexperience or understanding of the translation itself and also through other people, either directly or through the media, and what is notified can be accepted as something that considered correct. While the understanding of interpretation is $37 \%$, this result is in accordance with information from all respondents who were interviewed at the time of socialization, almost all of them answered that they did not know the products and services available in Islamic banks. Some people are already aware of the existence of Islamic banks, but they do not know the products offered by Islamic banks so that people who do not know the products of Islamic banks will certainly not be interested in using the services of Islamic banks because they consider that the supporting facilities provided are still inferior to those of Islamic banks. facilities offered by conventional banks. The understanding of exploitation by $12 \%$ is a little cup because this understanding who already understands Islamic banking and can explain it has already implemented it. 
2. Public Understanding of Islamic Banking after Socialization

The following table and pictures of Islamic Bank Respondents' Understanding Specifically before the socialization, are as follows:

Table 4

Understanding of Islamic Bank Respondents Specifically after Socialization

\begin{tabular}{|c|c|c|}
\hline No & Understanding Type & Amount \\
\hline 1. & Translation understanding & 12 \\
\hline 2. & Interpretive understanding & 23 \\
\hline 3. & Extrapolation understanding & 65 \\
\hline
\end{tabular}

Respondents' understanding of Islamic banks

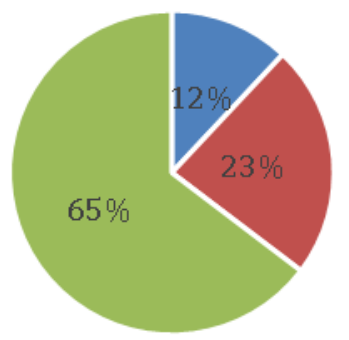

- translation understanding $\quad$ interpretation understanding

- extrapolation understanding

Figure 6

Understanding of Specific Respondents after Socialization is carried out

Based on Figure 4.16 the understanding of specific respondents after the socialization was carried out was inversely proportional to before the socialization was carried out, these results indicate that this socialization activity is running effectively so that it can be seen the understanding of exploitation or understanding that can compare and explain Islamic banking and apply it or have an account (become a customer of a Sharia bank). quite significant from $12 \%$ to $65 \%$ after socialization. This is because the public's interest in being curious is very good, which means that many people are able to see behind what is written, can make estimates, make predictions based on 


\section{Understanding Padangsidimpun City Community in Recognizing and Understanding Sharia Banking Products \\ Abdul Nasser Hasibuan dan Nofinawati}

ideas and are able to make conclusions from the results of the explanation of the materials presented by the speakers at the time of socialization.

\section{Conclusion}

From the results of the assistance in understanding and introducing Islamic banking products in the city of Padangsidimpuan, it can be concluded as follows:

1. Public understanding of sharia banking is only limited to knowing (instructional understanding) which before assistance was carried out was around 84\%, and increasing this understanding became an understanding of Islamic banking that had done (relationship understanding) or had used sharia banking services increased to $89 \%$ of which before the assistance was carried out, it was still around 14\% who understood Islamic banking.

2. Specific understanding of the people of Padangsdimpuan city, namely translation, interpretation, extrapolation about Islamic products and banking for the lowest level, namely the understanding of community translation of Islamic banking after permanent assistance is $12 \%$, while the second level is understanding of interpretation of the people of Padangsidimpuan city connecting the lowest parts with what is known next, or connecting with events, distinguishing the main from the non-essential has increased from $51 \%$ to $73 \%$, and for the third level is the highest level, namely the extrapolated understanding of the Padangsidimpuan city community regarding understanding that can distinguish something, so that it can explain it and have implemented it has increased from $37 \%$ to $63 \%$.

3. Ownership of Sharia Accounts and becoming sharia customers of the people of Padangsidimpuan City after mentoring has increased by $74 \%$.

\section{References}

Abdul Nasser Hasibuan, Strategi Pemasaran produk funding di PT.Pembiayaan Rakyar Syariah Padangsidimpuan, Jurnal Imara : 2018, http://ecampus.iainbatusangkar.ac.id/ojs/index.php/jurei/article/view/1032 $/ 1046$

Andri Soemitra, Bank dan Lembaga Keuangan Lainnya, Jakarta:Kencana, 2009. 
Anggota Ikapi, Undang-Undang Perbankan Syariah dan Surat Berharga Syariah Negara, Bandung: FokusMedia, 2008.,

Ascarya, (2006), Akad dan Produk Bank Syariah: Konsep dan Praktek di Beberapa Negara, Jakarta: PT Raja Grafindo

Didin Hafidhuddin, Zakat Dalam Perekonomian Modern, Jakarta: Gema Insani Press, 2002.

, Agar Harta Bertambah Berkah, Jakarta: Gema Insani Press, 2007.Edy Wibowo, dkk, (2005), Mengapa Memilih Bank Syariah, Bogor: Ghalia Indonesia cet.I.

Hendrik Budi Untung, Corporate Social Responsibility, Jakarta: Sinar Grafika, 2009.

Herman Darmawi, Pasar Finansial dan Lembaga-Lembaga Finansial, Jakarta: PT. Bumi Aksara, 2006.

Hery, Analisis Laporan Keuangan, Yogyakarta: CAPS, 2015.

IrhamFahmi, Analisis Laporan Keuangan, Bandung: Alfabeta, 2015.

Jumal Lulail Yunus, Manajemen Bank Syariah Mikro, Malang: UIN-Malang Press, 2009.

Jumingan, Analisis Laporan Keuangan, Jakarta: PT Bumi Aksara, 2011.

Jundiani, (2009), Pengaturan Hukum Perbankan Syariah di Indonesia, Malang: UIN Malang Press

Kasmir, Bank dan Lembaga Keuangan Lainnya, Jakarta: PT, Raja Grafindo Persada, 2007.

, Manajemen Perbankan, Jakarta: Rajawali, 2008.

Lukman Dendawijaya, Manajemen Perbankan, Jakarta: Ghalia Indonesia, 2009

M. Nur Rianto Al-Arif, (2008), Lembaga Keuangan Syariah: Suatu Kajian Teoritis Praktis, Bandung: CV Pustaka Setia

Nofinawati, Akad dan Produk Bank Syariah, (2014) Akad dan produk perbankan syariah. Fitrah: Jurnal Kajian Ilmu-ilmu Keislaman, 8 (2). pp. 219-234. ISSN 2442-6997 http://jurnal.iain-padangsidimpuan.ac.id/index.php

Rizal Yaya, Akuntansi Perbankan Syariah Edisi 2, Jakarta: Salemba Empat, 2016 


\section{Understanding Padangsidimpun City Community in Recognizing and Understanding Sharia Banking Products}

Abdul Nasser Hasibuan dan Nofinawati

Sutan Remy Sjahdeini, (2007),Perbankan Islam, Jakarta: PT Pustaka Utama Grafiti, cet ke-3.

Umrotul Khasanah, Manajemen Zakat Modern: Instrumen Pemberdayaan Ekonomi Umat, Malang: UIN-Maliki Press, 2010.

Wasilah dan Nurhayati Sri, Akuntansi Syariah di Indonesia: Edisi 2 Revisi, Jakarta: Salemba Empat, 2011.

Wiratna Sujarweni, Metodologi Penelitian, Yogyakarta: PustakaBaru Press, 2014.

Yayasan SPES, (1992), Pengembangan Berkelanjutan, Jakarta: PT. Pustaka Utama 